the electrical engineering point of view was at once appreciated, for if resistance were annihilated, huge amounts of power could be transmitted great distances by very thin wires. Practical applications, however, are still few and engineers await the further elucidation of the phenomenon by physicists. The action of a magnetic field in delaying the appearance of supra-conductivity wants further explanation. The experiments with direct and alternating currents seem to justify the conclusion that a polarisation or orientation phenomenon of some kind is involved in the production of the supra-conducting state in metals. The electron lattice theory is a promising one but in order to verify it a further study of the conductivity of single crystals at very low temperatures is necessary.

\section{Sir Thomas Purves}

THE retirement at the end of last month of Col. Sir Thomas Fortune Purves from the post of engineer-in-chief to the Post Office came after ten years of unparalleled development in the art of electrical communications. During his term of office, he had to decide whether the future of telephony in Great Britain was to be manual or automatic. His decision to adopt the Strowger step-by-step automatic system has been proved by experience to have been of great benefit to the country. His pleasing personality was of great value in the development of international telephony. At the conclusion of the War, everything was favourable for the establishment of an extensive European system, provided that national boundaries could be disregarded. The problem therefore was one of politics rather than of engineering, and it was in this field that Sir Thomas's great gifts as a diplomatist had full play. The disarming charm of his manner, his wit and geniality broke down all barriers. In 1924 he met the representatives of the German administration at the Hague and was successful in persuading them to come to the first international telephone conference which took place in April of that year. Since then, conferences of the C.C.I. (Comite Consultatif International) have been held every year. The retirement of a figure of the type of Sir Thomas Purves from these international deliberations will be very seriously felt throughout Europe. When appointed engineerin-chief in 1922, he prophesied that the coming ten years would see many remarkable developmentssuch as full intercommunication between the tele. phone systems of Great Britain and the United States-all of which have been duly accomplished. Great Britain has become the switching centre through which Europe and America communicate with each other and with the British Dominions. No radio centres in the world are comparable in magnitude with the Post Office transmitting centre at Rugby and receiving centre at Baldock. Sir Thomas is one of the most popular members of the council of the Institution of Electrical Engineers, of which he has been president. We hope he will be.able to do equally valuable work for many years to come. His successor at the Post Office is Lieut.-Col. A. G. Lee, chairman of the Radio Research Board.

\section{John Phillips and the Geology of Yorkshire}

THE annual meeting of the Yorkshire Geological Society was held at Leeds on November 19. The president, Mr. T. Sheppard, took as the subject of his address the work of John Phillips, the pioneer of Yorkshire geology. As a nephew and companion of William Srnith, Phillips had unique opportunities for applying the principles of stratigraphy, and his first book on the subject, "Illustrations of the Geology of Yorkshire. Part 1, The Yorkshire Coast", appeared in 1829 and went through three editions; but of Part 2, "The Mountain Limestone District", there is only one edition, 1836. His other book, "The Rivers, Mountains and Sea Coast of Yorkshire", is of a more popular type and includes an account of the "Ancient Inhabitants of the County". Both show his genius for conveying much solid and original geological work in eminently readable form and also his skill as an artist, the illustrations of scenery and fossils alike being from his pencil. It may here be mentioned that Phillips's fossil types, preserved in the York Museum, of which he was long the curator, have recently been carefully labelled and set out for study by Mr. S. Melmore. While at York, Phillips was one of the founders of the British Association, and Mr. Sheppard mentioned an occasion when he astonished the members by giving, without preparation, a surprisingly complete summary of the year's advances in all branches of science. His later work at Oxford and his well-known "Manual of Geology" were briefly mentioned, but $\mathrm{Mr}$. Sheppard promised that when his address was published it should include a complete bibliography. The task of compiling it could not be in more capable hands.

\section{Prof. Max Weber}

IN NATURE for December 9, 1922, there was published a letter of congratulation that had been sent by British zoologists to Prof. Max Weber, of Amsterdam, on the occasion of his seventieth birthday. Of the thirty-five who signed that letter, only twenty-five now survive, and these repeated their congratulations on December 5 last, when the distinguished Dutch zoologist completed his eightieth year. Prof. Weber, who has been a foreign member of the Linnean Society of London since 1898, also received a letter of congratulations from the council of that Society. In the last ten years, Prof. Weber's record of work would have done credit to the vigour of a man of half his age. He has brought out a second edition of his monumental textbook, "Die Säugethiere": he is still producing the successive volumes of the "Fishes of the Indo-Australian Archipelago", in collaboration with Dr. de Beaufort; and the reports of the Siboga expedition, written by contributors all over the world, continue to appear under his editorship with a regularity that editors of reports of less important expeditions may well envy.

\section{The British Dyestuffs Industry}

THE third report of the Dyestuffs Industry Development Committee on the present position and development of the dyestuffs manufacturing industry 